\title{
Sphenoid Sinus Squamous Cell
}

\section{Carcinoma}

National Cancer Institute

\section{Source}

National Cancer Institute. Sphenoid Sinus Squamous Cell Carcinoma. NCI Thesaurus.

Code C6066.

A squamous cell carcinoma that arises from the mucosal epithelial surface of the sphenoid sinus. Patients may present with nasal fullness, obstruction, and/or epistaxis. 